\title{
The Action of Bacteriophage $\Omega 8$ on Two Strains of Escherichia coli 08
}

\author{
By BARBARA WALLENFELS AND K. JANN \\ Max-Planck-Institut für Immunbiologie, Freiburg, Germany
}

(Received 27 July 1973; revised 3I August 1973)

\begin{abstract}
SUMMARY

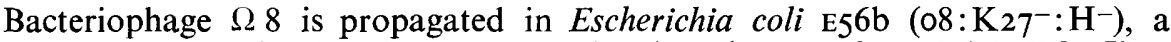
non-capsulated strain. Another non-capsulated strain, E. coli 2398 (08: K ? $\left.{ }^{-}: \mathrm{H}^{-}\right)$, is killed by bacteriophage $\Omega 8$ without phage propagation. This strain was formerly believed to be $E$. coli $093: \mathrm{K}^{-}: \mathrm{H}^{-}$, cross-reacting with strain E56b. We have established chemical and serological identity of the 08-specific lipopolysaccharides of the two strains.

The o8-specific lipopolysaccharides of both strains inhibited the infection of Escherichia coli E56b with bacteriophage $\Omega 8$ equally well. The adsorption rate constants of $\Omega 8$ were identical for the two strains of $E$. coli 08 . Evidence was obtained with ${ }^{32} \mathrm{P}$-labelled bacteriophage $\Omega 8$ for penetration of viral DNA into both bacterial strains. In host strain E56b, phage particle synthesis occurred normally. In strain 2398 the viral DNA was not degraded but its expression was blocked. The killing effect of $\Omega 8$ on $E$. coli strain 2398 is supposed to be due to damage of the cytoplasmic membrane, which could not be reversed under the influence of viral information. This was indicated by a blockage of cellular respiration, $\beta$-galactoside transport and RNA as well as protein synthesis.
\end{abstract}

\section{INTRODUCTION}

During immunochemical studies on the surface antigens of Escherichia coli we have analysed a number of somatic $O$ antigens (Ørskov et al. 1967). One of the strains studied, $E$. coli $\mathrm{H} 308$ b, was classified as $093: \mathrm{K}^{2} \mathrm{H}^{-}$. Its $\mathrm{O}$-antigenic lipopolysaccharide belongs to chemotype III, i.e. it contains mannose in addition to the common core sugars glucose, galactose, glucosamine, heptose and KDO (for definitions see Lüderitz, Staub \& Westphal, I966). From strain $\mathrm{H} 308$ b a non-capsulated $\left(\mathrm{K}^{-}\right)$mutant was isolated and designated as $E$. coli 2398 . Serological studies showed that this strain has the same $\mathrm{O}$ antigen as $E$. coli 08 . As a further proof of this identity we intended to use bacteriophage $\Omega 8$, which was previously found to be specific for non-capsulated E. coli 08 strains (Jann, Schmidt, Wallenfels $\&$ Freund-Mölbert, I 97I). Bacteriophage $\Omega 8$ adsorbed to strain 2398 and killed it without bacteriophage propagation, indicating that $E$. coli 2398 is a mutant or a variant of E. coli 08 which has the 08 antigen but does not allow multiplication of the 08 -specific bacteriophage $\Omega 8$. This killing by $\Omega 8$ without phage multiplication is described in the present communication.

\section{METHODS}

Media. Difco antibiotic medium 3 (M 3), supplemented with $4 \mathrm{~g}$ glucose/l was used for propagation of phage. Stock cultures of bacteria were kept on D I.5 agar (Schlecht \& Westphal, 1966). For titration of bacteriophage, Loeb agar (Loeb \& Zinder, I96I) was used. Preparation of ${ }^{32} \mathrm{P}$-labelled bacteriophage was performed in a medium containing 
(g/l) beef extract, $\mathrm{I} \cdot 5$; yeast extract, $\mathrm{I} \cdot 5$; peptone, 5 ; glucose, $\mathrm{I}$; and the phosphate-free mixture of inorganic salts described by Nomura, Matsubara, Okamoto \& Fujimura (I962).

Strains. Escherichia coli E56b (08: $\left.\mathrm{K}_{27}^{-7^{-}}: \mathrm{H}^{-}\right)$was used as host strain (Jann et al. 197I). The influence of bacteriophage $\Omega 8$ on physiological and biochemical processes was studied with $E$. coli 2398 which is a spontaneous non-capsulated $\left(\mathrm{K}^{-}\right)$mutant of $E$. coli $\mathrm{H} 308 \mathrm{~b}$. Strain 2398 removes all 08 -specific antibodies from an anti-08 antiserum. Serologically it is E. coli $08: \mathrm{K}^{-}: \mathrm{H}^{-}$.

High-titre stocks of purified bacteriophage. The bacteriophage was propagated on Escherichia coli $\mathrm{E} 56 \mathrm{~b}$ and purified by ammonium sulphate precipitation and isopycnic centrifugation in a discontinuous caesium chloride gradient (Jann et al. 1971). The resulting purified bacteriophage suspensions, which were kept in the presence of chloroform, usually had a titre of $5 \times 10^{12}$ p.f.u. $/ \mathrm{ml}$. Bacteriophage titres were determined by the overlayer method (Adams, 1959) using soft Loeb agar $(0.6 \%)$. Titrations were performed with $E$. coli E56b

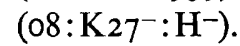

Isolation of bacterial lipopolysaccharides. The lipopolysaccharides ( $\mathrm{O}$ antigens) of Escherichia coli strains E56b and 2398 were extracted from whole bacteria with $45 \%$ aqueous phenol at $65^{\circ} \mathrm{C}$ (Westphal \& Jann, 1965). They were purified by repeated ultracentrifugation and freeze-dried. The yields of purified lipopolysaccharides were 2 to $4 \%$ of the bacterial dry weight.

Inhibition of infection by lipopolysaccharides. A modification of the method of Lindberg (1967) was described previously (Jann et al. 1971).

Polarographic determination of oxygen consumption. The time course of oxygen uptake was determined with infected and uninfected bacteria according to the method of Munder \& Modollel (1965). The apparatus consisted of a cultivation vessel which was divided by an oxygen-permeable Teflon membrane into two compartments, one to accommodate the bacterial suspension and the other for air. The latter compartment contained a Clark platinum electrode to measure the partial pressure of oxygen. The bacterial suspension was pipetted into one compartment, equilibrated at $37^{\circ} \mathrm{C}$ and infected with bacteriophage $\Omega 8$ (multiplicity of infection, m.o.i. $=7$ ). The change in the partial pressure was monitored by the platinum electrode and registered on a chart calibrated in torr units.

Transport of radioactive glycosides, amino acids and nucleotides into bacteria. Determinations were set up essentially as described by Duckworth (1970) and Winkler \& Duckworth (I97I). Overnight cultures of the two Escherichia coli strains were diluted I:50 with fresh M 3 medium and grown at $37^{\circ} \mathrm{C}$ with shaking for $\mathrm{I} \cdot 5$ to $2 \mathrm{~h}$. After this time the bacterial suspensions contained $2 \times 10^{8}$ to $3 \times 10^{8}$ organisms $/ \mathrm{ml}\left(E_{660 \mathrm{~nm}}=0 \cdot 12\right.$, measured with a I: $: 10$ dilution). The suspensions were then divided into equal portions, centrifuged at $4{ }^{\circ} \mathrm{C}$ and the sediments taken up in the original volume of $\mathrm{M} 3$ medium (at $37^{\circ} \mathrm{C}$ ). One portion of each strain was infected with bacteriophage $\Omega 8$ (m.o.i. $=6$ to 8$)$ and the other portion was used as a control. To all suspensions ( $\mathrm{I} 0 \mathrm{ml}$ ) the radioactive compounds were added. Final activities were: for methyl $\alpha-\left[{ }^{14} \mathrm{C}\right]$ glucoside and isoleucine, I $\mu \mathrm{Ci} / \mathrm{ml}$; for $\left[{ }^{3} \mathrm{H}\right]$ thymidine and $\left[{ }^{3} \mathrm{H}\right]$ uracil, $2 \mu \mathrm{Ci} / \mathrm{ml}$. The studies with $\left[{ }^{3} \mathrm{H}\right]$ thymidine were performed in the presence of adenosine.

After various times $0.5 \mathrm{ml}$ samples were passed through membrane filters (Sartorius no. I I 06, pore size $0.45 \mu \mathrm{m}$, diameter $25 \mathrm{~mm}$ ) and washed three times with $\mathrm{I} 5 \mathrm{ml}$ of ice-cold $0.85 \%$ $\mathrm{NaCl}$ solution. The filters were then dried and immersed into $10 \mathrm{ml}$ of scintillation fluid (I I g 2,5-diphenyloxazol, 0.24 g p-bis-(o-methylstyryl)benzol, I 1 Triton X-I00, 21 toluene). After $24 \mathrm{~h}$ the filters were dissolved and the samples were then counted in a Packard TRI CARB scintillation spectrometer. 
Transport of $\beta$-galactosides. This was measured with bacterial cultures which had been induced with isopropyl- $\beta$-thiogalactoside (IPTG) as described by Winkler \& Duckworth (I97I). For induction, overnight cultures of Escherichia coli strain E56b and 2398 were diluted I:50 with fresh M 3 medium without glucose which contained $5 \times 10^{-4} \mathrm{M}$-IPTG. After a I: Io dilution of the culture had reached an extinction of 0.13 , the suspension was centrifuged and the sediment taken up in the original volume of fresh $\mathrm{M}_{3}$ medium without glucose.

Of the suspensions of induced bacteria $9 \mathrm{ml}$ were infected with bacteriophage $\Omega 8$ (m.o.i. $=8$ ) and at the same time $\mathrm{I} \mathrm{ml}$ of $5 \times 10^{-2} \mathrm{M}-o$-nitrophenyl- $\beta$-galactoside (ONPG) in $2.5 \times \mathrm{IO}^{-2} \mathrm{M}$-phosphate buffer at $\mathrm{pH} 7.2$ was added. At various times $0.5 \mathrm{ml}$ portions of the mixtures were added to $\mathrm{I} \cdot 5 \mathrm{ml}$ of cold $\left(4{ }^{\circ} \mathrm{C}\right) 2 \mathrm{M}$-sodium carbonate. These samples were centrifuged in the cold $\left(4^{\circ} \mathrm{C}\right)$ and the extinction of the supernatants measured at $420 \mathrm{~nm}$ using a PMQ Zeiss spectrophotometer. A zero-time blank served as reference.

Incorporation of radioactive precursors into macromolecules. The method described above measures total transport of low molecular weight material across the bacterial membrane. When incorporation of amino acids into protein, uracil into RNA and thymidine into DNA was investigated, the incorporation was performed as above. After various times $0.5 \mathrm{ml}$ portions were added to $2.5 \mathrm{ml}$ of ice-cold water, which was immediately followed by the addition of $3 \mathrm{ml}$ of $10 \%$ trichloroacetic acid (TCA). The suspensions were thoroughly mixed, kept in ice for $5 \mathrm{~min}$ and filtered through a membrane filter (see above). The filters were washed twice with cold $\left(4{ }^{\circ} \mathrm{C}\right) 5 \%$ TCA and three times with cold $\left(4{ }^{\circ} \mathrm{C}\right)$ water, dried and counted as described above.

${ }^{32} P$-labelled bacteriophage. Escherichia coli $\mathrm{E} 56 \mathrm{~b}\left(08: \mathrm{K}_{2} 7^{-}: \mathrm{H}^{-}\right)$was grown overnight in GL-medium containing glycerol (Novick \& Brodsky, 1972), diluted I:50 with modified Nomura medium (Nomura et al. 1962; see Methods) and grown at $37^{\circ} \mathrm{C}$ with shaking. When the extinction of a $\mathrm{I}$ : Io diluted sample had reached a value of $0 . \mathrm{I} 2$ (corresponding to about $3 \times 10^{8}$ organisms $\left./ \mathrm{ml}\right), 0.4 \mathrm{ml}$ of $\left[{ }^{32} \mathrm{P}\right]$ orthophosphate $(10 \mathrm{mCi} / \mathrm{ml}$ ) was added. The final activity of the suspension was $4 \mu \mathrm{Ci} / \mathrm{ml}$. Five minutes after the addition of ${ }^{32} \mathrm{P}$ the culture was infected with bacteriophage $\Omega 8$ (m.o.i. $=4$ ) which had been dialysed overnight against phosphate-free buffer (Novick \& Brodsky, 1972). Thirty minutes after lysis of the bacteria, indicated by clearing of the suspension and foaming, the radioactive bacteriophages were isolated and purified as described by Jann et al. (I97I). The final suspension of radioactive bacteriophage $\Omega 8$ contained $5 \times 10^{11}$ p.f.u. $/ \mathrm{ml}$ and $5 \times 10^{6}$ c.p.m. $/ \mathrm{ml}$.

\section{RESULTS}

Interaction of bacteriophage $\Omega 8$ with Escherichia coli strains $\mathrm{E} 56 b$ and 2398

As our serological studies had shown that strains E56b and 2398 both have the 08 antigen, it was of interest to compare the action of o8-specific bacteriophage $\Omega 8$ on both strains.

When drops of serial dilutions ( $\mathrm{I}: \mathrm{IO}$ ) of $\Omega$ 8-suspensions were put on agar plates seeded with Escherichia coli E56b, confluent lysis was observed with dilutions down to $10^{4}$ p.f.u./ml; below this dilution single plaques formed. On E. coli 2398 confluent lysis was observed until diluted to $10^{8}$ p.f.u./ml; lower concentrations of the bacteriophage did not show any plaques. From these findings it can be concluded that either lysis from without had occurred on strain 2398 or that the bacteriophage exerted a bacteriostatic effect, so that at the spots where the suspension had been applied the bacterial lawn could not develop. In order to differentiate between these possibilities, we studied the effect of bacteriophage $\Omega 8$ on growing cultures of both strains. 


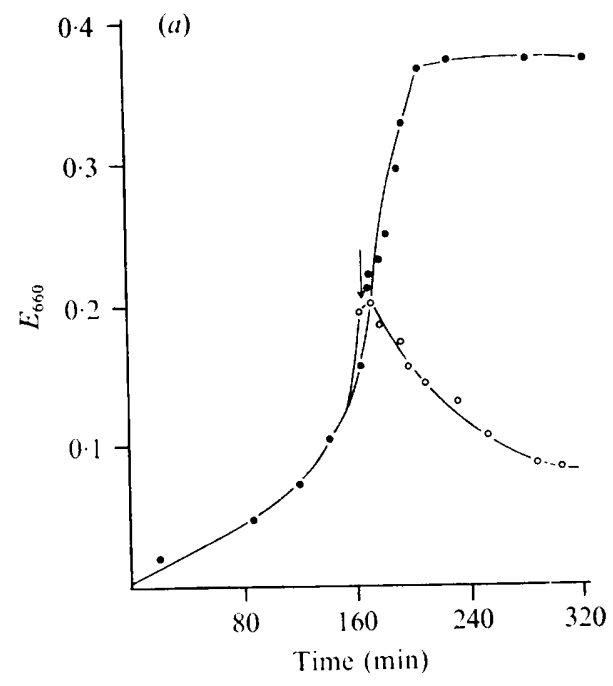

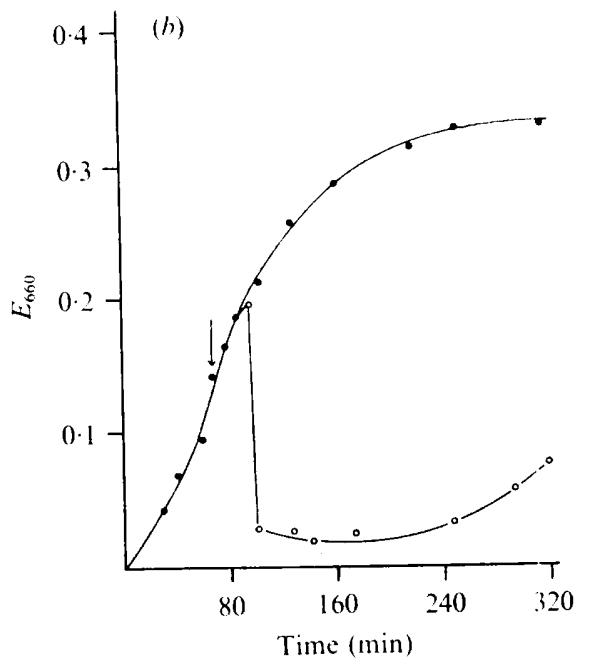

Fig. I

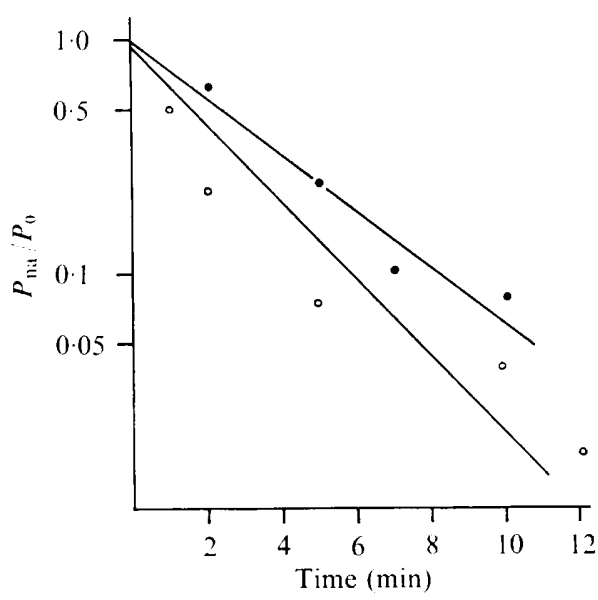

Fig. 2

Fig. I. Influence of bacteriophage $\Omega 8$ on growth of Escherichia coli $2398(a)$ and $E$. coli E56b $(b)$. Changes in extinction were measured at $660 \mathrm{~nm}$. O Uninfected sample showing the normal growth curve; $O$, sample after infection with $\Omega 8$ (m.o.i. $=7$ ).

Fig. 2. Kinetics of adsorption of bacteriophage $\Omega 8$ to host strain Escherichia coli $\mathrm{E} 56 \mathrm{~b}(O)$ and E. coli $2398(0)$. To $10 \mathrm{ml}$ of a suspension, containing $2 \times 10^{8}$ bacteria $/ \mathrm{ml}, 0 . \mathrm{I} \mathrm{ml} \mathrm{of} 0.1 \mathrm{M}-\mathrm{KCN}$ was added. The mixture was kept at $37^{\circ} \mathrm{C}$ for $2 \mathrm{~min}$ and then $0.1 \mathrm{ml}$ of bacteriophage suspension, containing $2 \times 10^{7}$ p.f.u. $/ \mathrm{ml}$, was added. Thus, the suspension originally contained $2 \times 10^{5}$ p.f.u. $/ \mathrm{ml}$ $\left(P_{0}\right)$. At the times indicated, $50 \mu \mathrm{l}$ portions were added to $5 \mathrm{ml} \mathrm{M} 3$ medium containing some drops of chloroform. The number of non-adsorbed phage particles $\left(P_{\mathrm{na}}\right)$ was determined by titration with host strain E56b. 
Overnight cultures of Escherichia coli strains E56b and 2398 were diluted I :50 with fresh M 3 medium and grown at $37^{\circ} \mathrm{C}$ with shaking. E. coli 2398 had a longer lag period than E56b. However, after entering the exponential growth phase both strains had the same generation time $\left(t_{g}=23 \mathrm{~min}\right)$ under the conditions used. When $E_{660}$ of a I : Io diluted sample was about $0 \cdot 15$, a suspension of bacteriophage $\Omega 8$ was added and the further growth of the cultures observed by measuring $E_{660}$. The results obtained with m.o.i. $=7$ are shown in Fig. I. E. coli $\mathrm{E} 56 \mathrm{~b}$ grew for a further 20 to $25 \mathrm{~min}$, which corresponds to the latent period of bacteriophage $\Omega 8$ in its host strain E56b (Jann et al. I97I). Lysis occurred very rapidly with clearing of the suspension, and was accompanied by liberation of phage progeny with a burst size of 125 (not shown here: see Jann et al. I97I). In contrast, infection of strain 2398 with bacteriophage $\Omega 8$ resulted in an immediate blockage of bacterial growth. This was followed about Io min later by slow lysis of the bacteria but no propagation of bacteriophage $\Omega 8$ took place. The action of bacteriophage $\Omega 8$ on E. coli 2398 occurred at a comparable rate at m.o.i. $=2$ to 8 . At higher multiplicities lysis of bacteria was more rapid.

\section{Comparative studies on the $\Omega$ 8-receptor of Escherichia coli strains $\mathrm{E} 56 b$ and 2398}

The adsorption of bacteriophage $\Omega 8$ on Escherichia coli 2398 may be less effective than that on $E$. coli $\mathrm{E} 56 \mathrm{~b}$ and we therefore studied the kinetics of adsorption of the bacteriophage on both bacterial strains (Fig. 2) from which the following adsorption rate constants were calculated: $K_{\mathrm{E} 56 \mathrm{~b}}=\mathrm{I} \cdot 53 \times \mathrm{IO}^{-13} \mathrm{ml} / \mathrm{min}$ and $K_{2398}=\mathrm{I} \cdot 38 \times 10^{-13} \mathrm{ml} / \mathrm{min}$. As these values are practically identical, the adsorption of the bacteriophage is equally effective with both $E$. coli strains.

The 08 -specific lipopolysaccharide of Escherichia coli E56b is the $\Omega$ 8-receptor and removal of the fatty-acid substituents by hydrazinolysis does not alter its receptor properties (Jann et al. I97I ; Reske, Wallenfels \& Jann, I973). The results of the adsorption kinetics were therefore compared with the relative inhibitory capacities of the respective lipopolysaccharides on the infection of $E$. coli E56b with bacteriophage $\Omega$. The lipopolysaccharides from both strains inhibit the infection of $E$. coli E56b with bacteriophage $\Omega 8$ equally well. Treatment of both lipopolysaccharides with anhydrous hydrazine did not change their inhibitory capacities.

These results show that the failure of strain 2398 to propagate bacteriophage $\Omega 8$ is not because of imperfect adsorption of the bacteriophage on to a receptor structure different from the one of host strain $556 \mathrm{~b}$.

\section{Infection of Escherichia coli 2398 in the presence of sucrose}

The adsorption of bacteriophage $\Omega 8$ to organisms of strain 2398 was apparently the same as that to organisms of host strain E56b. Killing of strain 2398 , followed by slow lysis, might be caused by the action of muralytic enzyme(s) of the bacteriophage to which strain 2398 may be more sensitive and which render the bacteria osmotically fragile. Thus, normal bacteriophage propagation may have been affected by lysis of the host cell.

To test this possibility, we infected Escherichia coli 2398 with bacteriophage $\Omega 8$ (m.o.i. = 5) in $\mathbf{M}_{3}$ medium containing $\mathrm{I} 2 \%$ sucrose, under which conditions spheroplasts are osmotically stable (Birdsell \& Cota-Robles, I967); bacterial growth stopped rapidly. The ensuing lysis was slower than in experiments without sucrose, and there was no propagation of bacteriophage. As an additional test, bacteriophage $\Omega 8$ was titrated with $E$. coli 2398 with the overlayer method in the presence of $12 \%$ sucrose. This did not change the results obtained without sucrose: only diffuse lysis with higher concentrations of bacteriophage was observed, and single plaques which would indicate propagation of bacteriophage $\Omega 8$ 
did not occur. Hence, the killing effect of bacteriophage $\Omega 8$ on E. coli 2398 and the failure of this strain to propagate $\Omega 8$ were not due to the interfering action of muralytic bacteriophage enzyme(s).

\section{Initial fate of viral DNA in strains $\mathrm{E} 56 b$ and 2398}

The fact that bacteriophage $\Omega 8$ is not propagated in Escherichia coli 2398 posed the question whether the viral DNA entered into 2398-cells and, if so, what its initial fate was (degradation by restriction enzymes, etc.). To see whether there is a difference in the fate of the viral DNA in the two E. coli strains both were infected with ${ }^{32} \mathrm{P}$-labelled bacteriophage $\Omega 8$ with m.o.i. $=6$. After $3 \mathrm{~min}$ the mixtures were centrifuged at $3000 \mathrm{~g}$ and the radioactivity of the sediments established. E. coli E56b had $90 \%$ and E. coli 2398 had $85 \%$ of the original activity retained. These were taken as adsorbed radioactive bacteriophage and treated as total values in the following experiments:

(I) To investigate whether the radioactivity could be removed from the bacterial cells, the sediment was shaken repeatedly with 50 mM-borate/6 mm-EDTA ( $\mathrm{pH} 9 \cdot 1$ ), conditions that remove bacteriophage $\phi \mathrm{XI}_{74}$ from bacteria to which it is adsorbed (Newbold \& Sinsheimer, 1970). This treatment removed $12 \%$ of the total activity from Escherichia coli E56b and $14 \%$ from $E$. coli 2398 . Thus the radioactive DNA had either entered the bacteria (which is certainly the case with strain E56b) or was still in the bacteriophage $\Omega 8$ which, unlike $\phi \mathrm{XI}_{174}$, was not removed from the bacteria by the borate/EDTA treatment.

(2) To test further whether the viral DNA penetrated into both Escherichia coli strains, the cells, after infection with [32P]bacteriophage, were lysed by shaking with chloroform and by addition of EDTA/lysozyme (Fujimura \& Kaesberg, 1962), respectively. After removal of EDTA or chloroform (dialysis or percolation with nitrogen) the radioactivity present in TCA-insoluble form (DNA) and in TCA-soluble form (DNA fragments) was determined. This was investigated with and without prior incubation with DNase. Independent of the mode of lysis, with the host strain $\mathrm{E} 56 \mathrm{~b} 87 \%$ of the radioactivity was insoluble in $5 \%$ TCA and $13 \%$ was soluble. After treatment of the lysate with DNase for $20 \mathrm{~min}, 9 \%$ was still insoluble and 91 \% was TCA-soluble. Similar results were obtained with the lysate from infected $E$. coli 2398 . Before treatment with DNase, $70 \%$ of the radioactivity was TCAinsoluble and $30 \%$ was TCA-soluble. After DNase treatment $25 \%$ was still TCAinsoluble and $75 \%$ was TCA-soluble.

These results strongly indicate that in both strains (E56b and 2398) the viral DNA was injected after adsorption of the bacteriophage and that it was only slightly degraded by cellular enzymes.

\section{Influence of bacteriophage $\Omega 8$ on bacterial respiration}

A possible mode of killing Escherichia coli 2398 by bacteriophage $\Omega 8$ may be by way of disturbance of the cytoplasmic membrane. This would result in interference with membrane functions and finally lead to cell death. Redox processes are important membrane functions which can be tested by measuring the oxygen consumption (cell respiration). The results of the polarographic measurements of oxygen uptake by strains E56b and 2398 and the influence of bacteriophage $\Omega 8$ on it (Fig. 3) revealed that during the first 25 min there was no influence of $\Omega 8$ on respiration of strain E56b. In contrast, $\Omega 8$ effected an immediate diminution of the oxygen uptake of strain 2398 . After about 30 min the oxygen uptake increased again, due to R-mutants which formed to a greater extent from E. coli 2398 under the unfavourable conditions of the experiment, as was shown by their isolation.

These results indicated that the bacterial membrane of Escherichia coli 2398 was damaged by bacteriophage $\Omega 8$. 


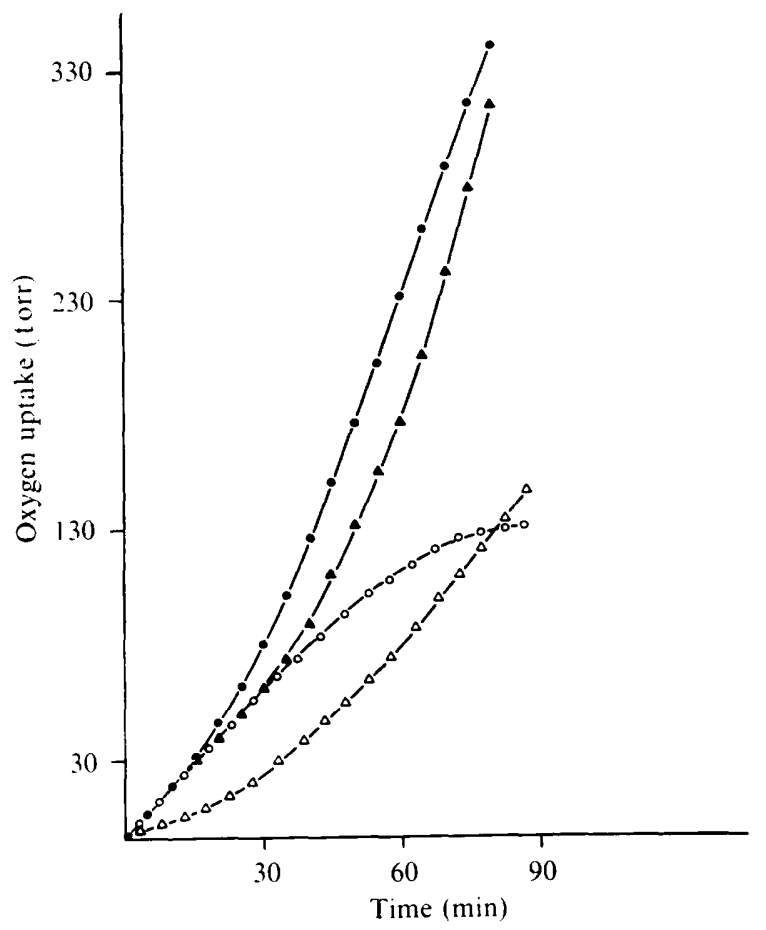

Fig. 3. Oxygen consumption of Escherichia coli strains E56b and 2398 after infection with bacteriophage $\Omega 8$ (m.o.i. $=7$ ). Measurements were made on $6 \mathrm{ml}$ bacteria $\left(3 \times 10^{8}\right.$ cells $\left./ \mathrm{ml}\right)$. Measurement of partial pressure of oxygen began $4 \mathrm{~min}$ after infection.,$E$. coli $\mathrm{E} 56 \mathrm{~b}$ in the absence of phage; $\Delta, E$. coli 2398 in the absence of phage; O, E. coli E56b in the presence of phage; $\triangle$, E. coli 2398 in the presence of phage.

\section{Influence of bacteriophage $\Omega 8$ on glycoside transport}

Methyl glucoside transport. Methyl $\alpha$-glucoside, glucose and a number of other monosaccharides are taken up by bacterial cells through vectorial phosphorylation with the phospho-enol-pyruvate (PEP) system (Kundig, Ghosh \& Roseman, 1964; Kundig, Kundig, Anderson \& Roseman, 1966; Simoni, Smith \& Roseman, 1968; Kornberg, 1973). We chose methyl- $\alpha-\left[{ }^{14} \mathrm{C}\right]$ glucose which is a non-metabolizable analogue of glucose. The rate of uptake was measured as the intracellular accumulation of radioactivity. The experiments were performed with Escherichia coli strains E56b and 2398 in a glucose-free M 3 medium containing $0.1 \%$ glycerol. Two minutes after infection with bacteriophage $\Omega 8$ (m.o.i. $=8$ ) methyl- $\alpha-\left[{ }^{14} \mathrm{C}\right]$ glucose was added, and after various times samples were removed and the washed cells assayed. There is no difference in glucoside uptake between bacteriophagepropagating bacteria (strain E56b) and those killed by the bacteriophage (strain 2398) (Fig. 4).

$\beta$-Galactoside transport. In bacteria with an induced lac-operon, $\beta$-galactosides are transported into the cell under the action of $\beta$-galactoside permease (Horecker, Thomas \& Monod, 1960) and then hydrolysed by another enzyme of the lac-operon, $\beta$-galactosidase. Thus, utilization of $\beta$-galactosides in Escherichia coli occurs via the sequential action of two enzymes of the lac-operon (Rickenberg, Cohen, Butting \& Monod, 1956); because $\beta$-galactoside uptake is rate-limiting in this process (Rickenberg et al. I956), intracellular hydrolysis of $\beta$-galactosides can be taken as a measure of $\beta$-galactoside permeation. This 


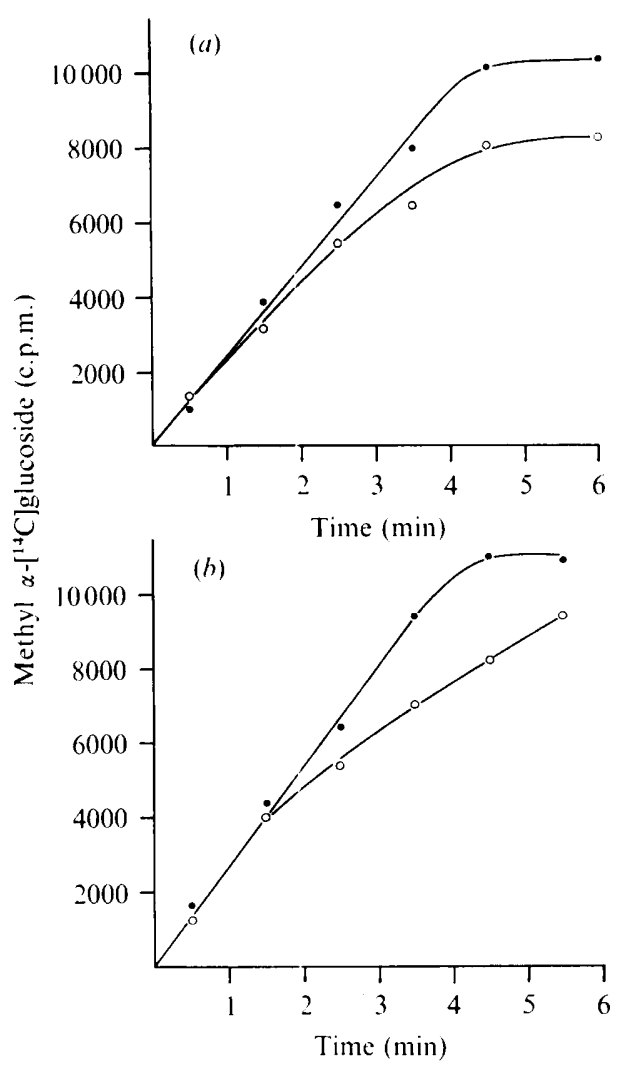

Fig. 4. Rate of uptake of methyl $\alpha-\left[{ }^{[4} \mathrm{C}\right]$ glucoside into Escherichia coli $2398(a)$ and $E$. coli $\mathrm{E} 56 \mathrm{~b}(b)$. $\bullet$, Transport in the absence of phage; $\bigcirc$, transport in the presence of phage. Infection (m.o.i. $=8$ ) was $2 \mathrm{~min}$ before the addition of the radioactive compound (i.e. at time $-2 \mathrm{~min}$ ). Experimental details are given in the text.

is usually measured with $o$-nitrophenyl-galactoside (ONPG) which upon hydrolysis liberates $o$-nitrophenol. This diffuses out of the cells and may be measured optically in alkaline medium (Pardee, Jacob \& Monod, I959; Winkler \& Wilson, I965).

Escherichia coli strains E56b and 2398 were grown in glucose-free medium to circumvent catabolite repression (Loomis \& Magasanik, I964; Nakada \& Magasanik, I964). The organisms were induced with IPTG 2 h before infection with bacteriophage $\Omega 8$ (m.o.i. $=8)$. Bacteriophage and ONPG were added simultaneously, samples removed after various times, and the $o$-nitrophenol liberated was measured. In $E$. coli $2398 \beta$-galactoside transport stopped immediately after infection, whereas in $E$. coli $\mathrm{E}_{56 \mathrm{~b}}$ only a slight decrease of transport activity could be detected after about $3 \mathrm{~min}$ (Fig. 5).

The effect of bacteriophage $\Omega 8$ on the induction of the lac-operon was the same with both Escherichia coli strains: when the inducer was added before infection, synthesis of $\beta$-galactosidase stopped about $5 \mathrm{~min}$ after infection with bacteriophage $\Omega 8$. When the cells were infected immediately ( $15 \mathrm{~s}$ ) before addition of IPTG, no $\beta$-galactosidase was formed at all (results not shown). 

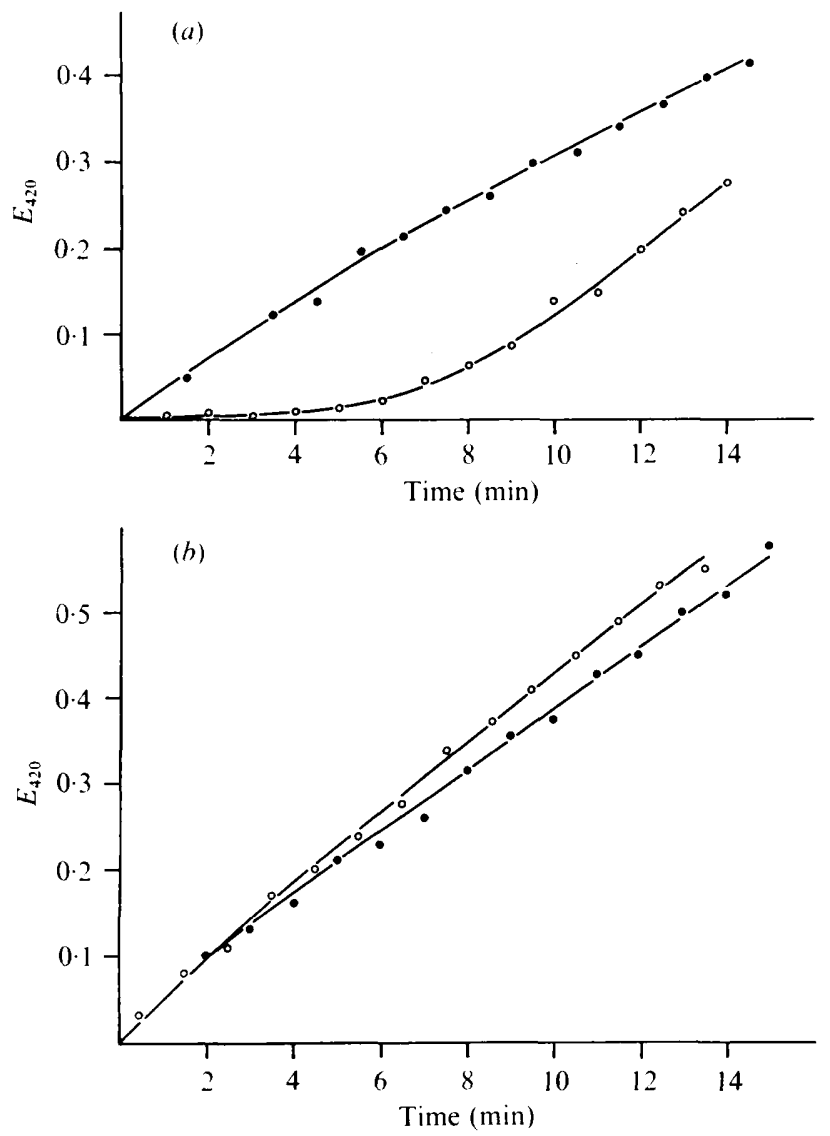

Fig. 5. Rate of uptake of $o$-nitrophenyl-galactoside (ONPG) in Escherichia coli $2398(a)$ and E. coli E56b $(b)$ after induction of the lac-operon. The transport was measured through the co-induced $\beta$-galactosidase activity. Infection (m.o.i. $=8$ ) was $2 \mathrm{~min}$ before the addition of the radioactive compound (i.e. at time $-2 \mathrm{~min}$ ). $\odot$, Transport in the absence of phage; $\bigcirc$, transport in the presence of phage. Experimental details are given in the text.

\section{Influence of bacteriophage $\Omega 8$ on synthesis of macromolecules and transport of monomeric precursors}

Protein biosynthesis and amino acid transport. To Escherichia coli strains E56b and 2398, suspended in $\mathrm{M} 3$ medium, $\left[{ }^{14} \mathrm{C}\right]$ isoleucine was added 2 min after infection (m.o.i. = 7). The total uptake of radioactivity, measured with washed bacteria, was equated with transport of this amino acid. For estimation of incorporation into protein, the bacteria were extracted with cold $5 \%$ TCA before they were washed and counted. In host strain E56b, uptake of isoleucine and incorporation into TCA-insoluble material was not affected until 7 min after infection and then continued at a reduced rate. In strain 2398, reduction of isoleucine uptake and incorporation into TCA-insoluble material was observed 3 min after infection and both stopped altogether after 8 to $9 \mathrm{~min}$. This is shown in Fig. 6 .

$R N A$ biosynthesis and uracil transport. The reaction was performed with $\left[{ }^{3} \mathrm{H}\right]$ uracil as described for $\left[{ }^{14} \mathrm{C}\right]$ isoleucine. Infection at a m.o.i. of 7 was $2 \mathrm{~min}$ before addition of $\left[{ }^{3} \mathrm{H}\right]$ uracil. As shown in Fig. 7, in host strain E56b uracil transport and RNA synthesis were affected immediately and RNA synthesis continued at a residual reduced rate. In strain 2398 uptake 


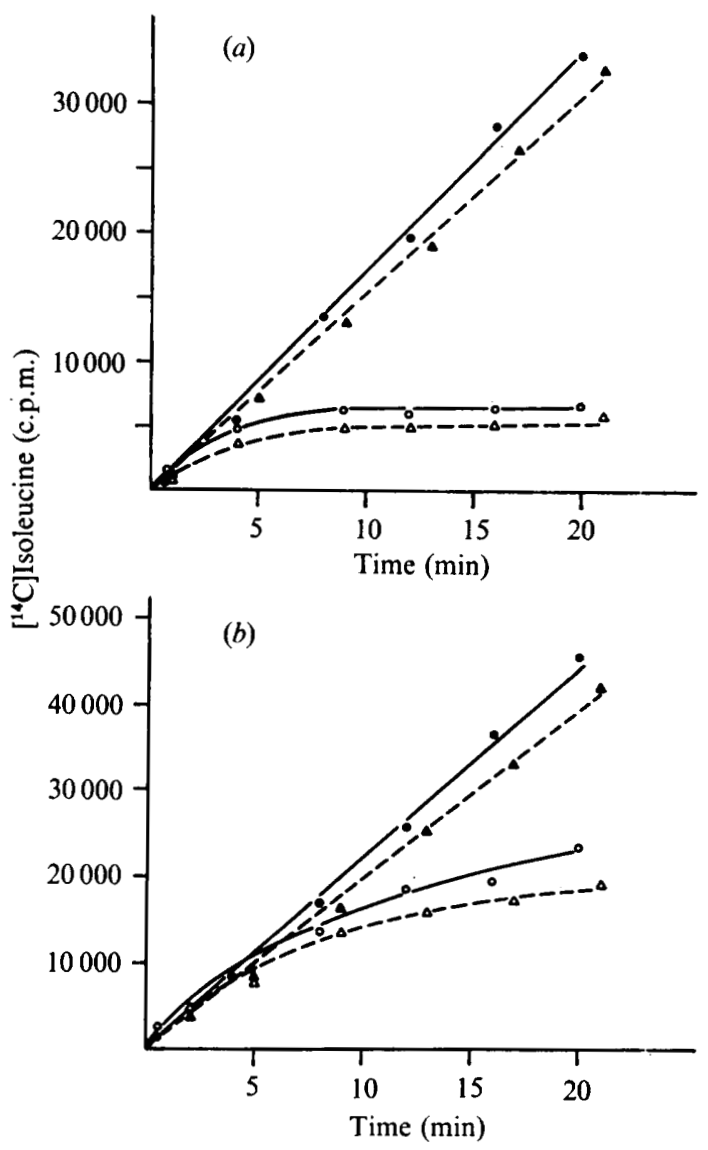

Fig. 6

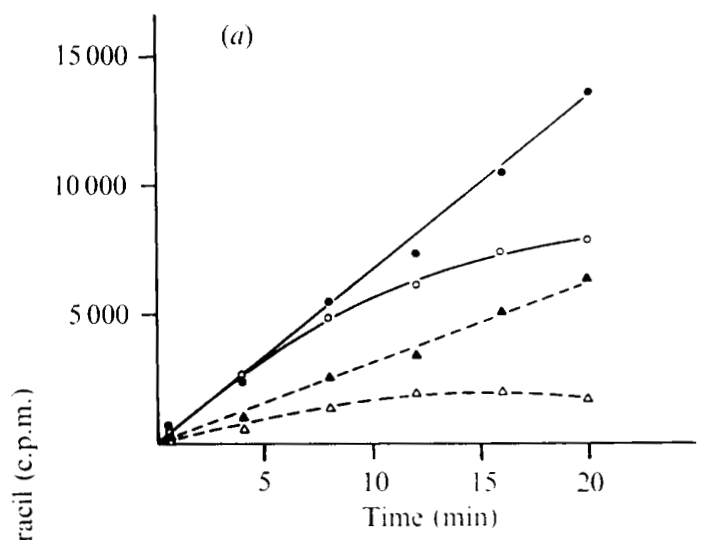

(b)

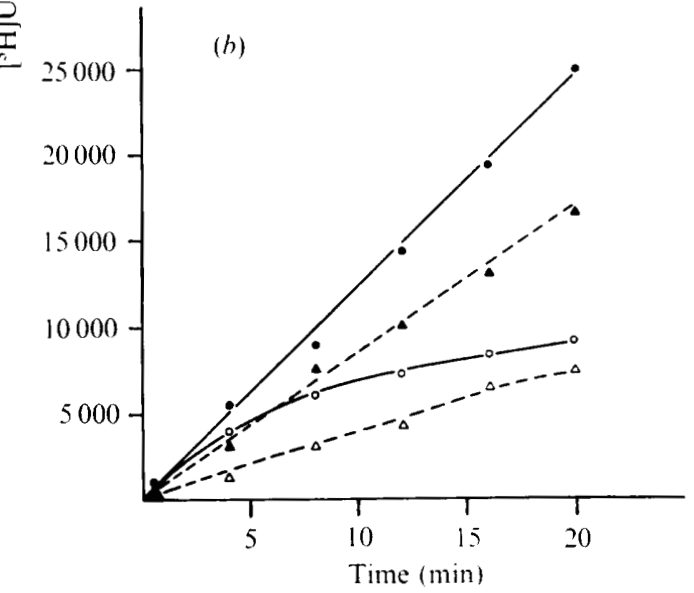

Fig. 7

Fig. 6. Rate of uptake of $\left[{ }^{14} \mathrm{C}\right]$ isoleucine and protein synthesis in Escherichia coli 2398 (a) and E. coli $\mathrm{E} 56 \mathrm{~b}(b)$, suspended in $\mathrm{M} 3$ medium ( $10^{8} \mathrm{cells} / \mathrm{ml}$ medium). Protein synthesis was measured as incorporation of radioactivity into TCA-insoluble material. Infection (m.o.i. $=7$ ) was 2 min before the addition of the radioactive compound (i.e. at time $-2 \mathrm{~min}$ ). $\bullet$, Isoleucine transport in the absence of phage; $\boldsymbol{\Delta}$, protein synthesis in the absence of phage; 0 , isoleucine transport in the presence of phage; $\Delta$, protein synthesis in the presence of phage. Experimental details are given in the text.

Fig. 7. Rate of uptake of $\left[{ }^{3} \mathrm{H}\right]$ uracil and RNA synthesis in Escherichia coli 2398 (a) and E. coli E56b (b). RNA synthesis was measured as incorporation of radioactivity into TCA-insoluble material. Infection (m.o.i. $=7$ ) was 2 min before the addition of the radioactive compound (i.e. at time $-2 \mathrm{~min}$ ). 0 , Uracil transport in the absence of phage; $\Delta$, RNA synthesis in the absence of phage; $O$, uracil transport in the presence of phage; $\triangle$, RNA synthesis in the presence of phage. Experimental details are given in the text.

of uracil continued at the initial rate until 8 to $10 \mathrm{~min}$ after infection and then decreased; RNA synthesis was immediately reduced and stopped altogether after 8 to $9 \mathrm{~min}$.

DNA biosynthesis and thymidine transport. Transport of $\left[{ }^{3} \mathrm{H}\right]$ thymidine was measured by total incorporation of radioactivity and DNA synthesis by incorporation into TCA-insoluble material, as described above. Thymidine induces thymidine phosphorylase, which hydrolyses thymidine to thymine (Rachelmeyer, Gerhart \& Rosner, 1961; Yagil \& Rosner, I970). Thus incorporation of thymidine into DNA is prevented. Because adenosine inhibits the enzyme, we performed the incorporation studies in its presence. Infection (m.o.i. $=6$ ) 


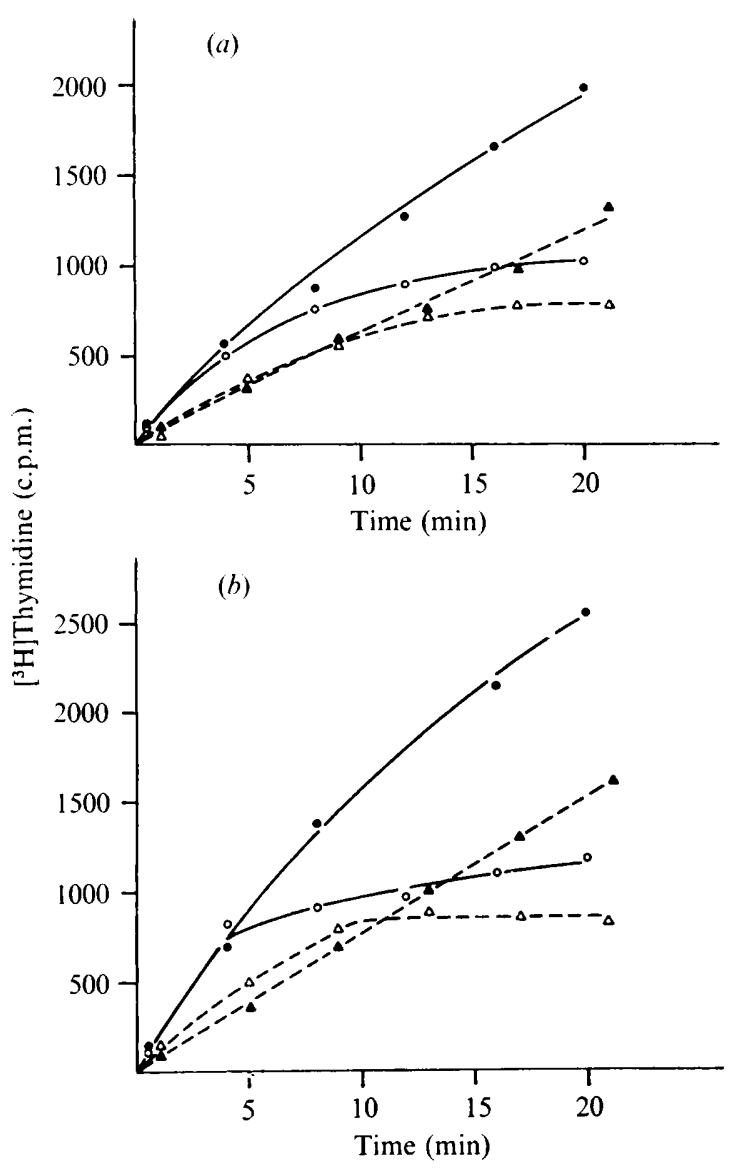

Fig. 8. Rate of uptake of $\left[{ }^{3} \mathrm{H}\right]$ thymidine and DNA synthesis in Escherichia coli $2398(a)$ and $E$. coli E56b (b). DNA synthesis was measured as incorporation of radioactivity into TCA-insoluble material. Infection (m.o.i. $=6$ ) was 2 min before the addition of the radioactive compound (i.e. at time $-2 \mathrm{~min})$. Thymidine transport in the absence of phage; $\boldsymbol{\Delta}$, DNA synthesis in the absence of phage; $O$, thymidine transport in the presence of phage; $\triangle$, DNA synthesis in the presence of phage. Experimental details are given in the text.

was $2 \mathrm{~min}$ before the addition of $\left[{ }^{3} \mathrm{H}\right]$ thymidine. In both strains DNA synthesis stopped about Io to $12 \mathrm{~min}$ after infection whereas transport of $\left[{ }^{3} \mathrm{H}\right]$ thymidine into the bacteria was markedly decreased but continued at a residual constant rate (Fig. 8).

\section{DISCUSSION}

These investigations compare the action of bacteriophage $\Omega 8$ on two Escherichia coli strains. In strain $\mathrm{E} 56 \mathrm{~b}\left(08: \mathrm{K}_{2} 7^{-}: \mathrm{H}^{-}\right)$the bacteriophage was propagated as described by Jann et al. (197I), who also showed that the bacteriophage receptor was the 08-specific lipopolysaccharide of $E$. coli $\mathrm{E} 56 \mathrm{~b}$. Bacteriophage $\Omega 8$ also adsorbed to strain 2398 . However, this was not followed by propagation of $\Omega 8$ but the strain was killed in the event. This E. coli strain was given the seroformula $093: \mathrm{K}^{--}: \mathrm{H}^{-}$and it was a non-capsulated mutant of strain H308b (Ørskov et al. 1967). Thus the two strains supposedly had different but serologically cross-reacting (i.e. partially identical) O-antigenic lipopolysaccharides. We therefore considered that the failure of bacteriophage $\Omega 8$ to multiply in strain 2398 might 
be due to ineffective adsorption of the phage on the bacterial surface. However, comparative studies of the adsorption kinetics with both bacterial strains showed that bacteriophage $\Omega 8$ adsorbed equally well on both (i.e. identical K-values). Also, the O-antigenic lipopolysaccharides of both strains inhibited the infection of host strain E56b by bacteriophage $\Omega 8$ equally well. The reason for this became clear when we found that both $E$. coli strains have the same 08-specific lipopolysaccharide (K. Jann \& K. Reske, unpublished observations). Thus they are two variant forms of $E$. coli 08 .

Two main questions are posed by the foregoing facts: Why is bacteriophage $\Omega 8$ propagated in one of the two E. coli 08 strains (E56b) and not in the other (2398)? Why is strain 2398 killed almost instantaneously by bacteriophage $\Omega 8$ whereas the host strain continues to grow for about 20 to $25 \mathrm{~min}$ (latent period), and what is the lethal effect exerted by bacteriophage $\Omega 8$ on strain 2398 ?

Failure of a bacteriophage to multiply in a bacterium which has the necessary receptor on its surface could be due to a variety of reasons: adsorption might not lead to entrance of the viral DNA into the bacterial cell; if injection occurred, the viral DNA could be rapidly degraded by bacterial restriction enzymes; if the viral DNA entered the cell and was not degraded, its expression could be blocked. We studied the fate of $\Omega 8$ DNA in the very first stages of infection, using a ${ }^{32} \mathrm{P}$-labelled bacteriophage $\Omega 8$ preparation. The adsorbed radioactivity could not be removed from the bacteria with EDTA/borate. This is in contrast to what was reported with $\phi \mathrm{X}_{\mathrm{I}} 74$ (Newbold \& Sinsheimer, I970).

Either the DNA was still within the bacteriophage, attached to the bacterial cell, or it had been injected and the phage ghost may or may not have been removed by EDTA/borate. When bacteria infected with ${ }^{32} \mathrm{P}$-labelled bacteriophage $\Omega 8$ were lysed, the lysates contained the radioactivity in a TCA-insoluble form. After incubation of the lysates from either strain with DNase practically all the radioactivity was soluble in TCA. Thus the DNA of bacteriophage $\Omega 8$ was injected into the cells of both Escherichia coli strains. In both cases the viral DNA was not degraded. Therefore the failure of E. coli 2398 to propagate bacteriophage $\Omega 8$ cannot be due to restriction but to some blockage in the ensuing stages of phage particle synthesis.

It was postulated that one of the very early effects of infection by bacteriophages is the allosteric alteration of the cytoplasmic membrane, which is indicated by changes in the turbidity of bacterial cultures (Puck \& Lee, 1954) and leakage of intracellular material (Puck \& Lee, 1954, I955). In normal infections of host bacteria these early effects are rapidly overcome by the action of repair mechanisms under bacteriophage control (Puck \& Lee, I954, 1955; see also Mathews, I97I). Under conditions where viral DNA cannot be expressed, repair of the initial damage of the cytoplasmic membrane does not occur and may even be magnified by co-operative effects (Mathews, I97I ; Changeux, Thiery, Tung \& Kittel, 1967). Such a general mechanism has been proposed for the action of colicines (Changeux \& Thiery, 1967) and seems to hold also for those of bacteriophage ghosts (Luria, 1964; Duckworth, 1970; Winkler \& Duckworth, 197I).

With respect to Escherichia coli E56b, such early effects were possibly repaired and propagation took place. In E. coli 2398 , however, it is conceivable that such a repair could not take place because expression of viral DNA was blocked. One may therefore speculate that lack of viral DNA expression (no propagation) in strain 2398 caused the killing of these bacteria. As the lethal action of bacteriophage $\Omega 8$ resembled those of colicins and bacteriophage ghosts, we studied the influence of $\Omega 8$ on membrane activities, such as transport, respiration and synthesis of macromolecules, in both strains.

Cell respiration was almost totally stopped immediately after infection of strain 2398 
but continued in strain $\mathrm{E} 56 \mathrm{~b}$ for a period which corresponded to the eclipse period of $\Omega 8$. The effect of bacteriophage $\Omega 8$ on two independent glycoside transport systems revealed different sensitivities. The PEP-dependent transport of methyl $\alpha$-glucoside was only slightly affected in both Escherichia coli strains. In induced cultures $\beta$-galactoside transport was immediately blocked by $\Omega 8$ in $E$. coli 2398 and only slightly affected in host strain E56b. Infection with $\Omega 8$ interfered with the inducibility of the lac-operon in both strains (synthesis of $\beta$-galactosidase blocked). However, no conclusion can be arrived at concerning the mechanism of this effect in the two strains from these results. The transport of isoleucine, uracil and thymidine was in each case slightly affected in host strain E56b and more drastically in strain 2398 in which transport was blocked altogether after about 8 min. In strain 2398 protein synthesis (expressed as incorporation of isoleucine) and RNA synthesis were both drastically reduced for the first 6 to $8 \mathrm{~min}$ after infection and then stopped altogether. In strain 556 b both were reduced but considerable residual activity could be measured throughout the experiment. There was no apparent difference in the synthesis of DNA between the two infected $E$. coli strains.

These facts, taken together with those obtained with ${ }^{32} \mathrm{P}$-labelled bacteriophage $\Omega 8$, are in accord with the conclusion that bacteriophage $\Omega 8$ was not propagated in Escherichia coli 2398 because of a disturbed synthesis of bacteriophage particles in this strain (possibly at the level of transcription or translation). As a concomitant effect, the cytoplasmic membranes of the bacterial cells were damaged, leading to repression and/or blockage of some membrane activities. These effects were not seen in host strain E56b.

Killing by a bacteriophage of a bacterium which has the bacteriophage receptor, without propagation of phage progeny, may be a more widespread phenomenon than is generally recognized. The two Escherichia coli strains we describe, which cannot be differentiated by immunochemists and serologists, provide an interesting example for the study of bacteriophage action on different bacterial cells which have the same bacteriophage receptor.

This publication is dedicated to Professor Dr O. Westphal on his 6oth birthday. The work was supported by a grant from the Deutsche Forschungsgemeinschaft.

\section{REFERENCES}

Adams, M. H. (1959). Bacteriophages, pp. 46I-469. New York: Interscience.

Birdsell, D. C. \& Cota-Robles, E. H. (1967). Production and ultrastructure of lysozyme and EDTAlysozyme spheroplasts of E. coli. Journal of Bacteriology 93, 427-437.

ChangeuX, J. P. \& Thiery, J. (1967). On the mode of action of colicins: a model of regulation at the membrane level. Journal of Theoretical Biology 17,3 I 5-3I8.

ChangeuX, J. P., Thiery, J., Tung, Y. \& Kittel, C. (I967). On the co-operativity of biological membranes. Proceedings of the National Academy of Sciences of the United States of America 57, 335-34I.

DuckworTH, D. H. (I970). The metabolism of T4 phage ghost-infected cells. I. Macromolecular synthesis and transport of nucleic acid and protein precursors. Virology 4o, 673-684.

Fujimura, R. \& Kaesberg, P. (1962). The adsorption of bacteriophage XI 74 to its host. Biophysical Journal 2, 433-449.

Horecker, B. L., Thomas, J. \& Monod, J. (1960). Galactose transport in Escherichia coli. I. General properties as studied in a galactose kinase-less mutant. Journal of Molecular Biology 13, I 57-170.

JANN, K., SChmidt, G., Wallenfels, B. \& Freund-Mölbert, E. (I97I). Isolation and characterization of Escherichia coli bacteriophage $\Omega 8$ specific for $E$. coli strains belonging to sero-group o8. Journal of General Microbiology 67, 289-297.

Kornberg, H. L. (1973). Carbohydrate transport by microorganisms. Proceedings of the Royal Society B I83, $105-123$.

Kundig, W., Ghosh, S. \& Roseman, S. (I964). Phosphate bound to histidine in a protein as intermediate in a novel phosphotransport system. Proceedings of the National Academy of Sciences of the United States of America 52, 1067-I074. 
Kundig, W., Kundig, F. D., Anderson, B. \& Roseman, S. (1966). Restoration of active transport of glycosides in Escherichia coli by a component of a phosphotransferase system. Journal of Biological Chemistry 241, 3243-3246.

LindBerg, A. A. (1967). Studies of a receptor for Felix O-I phage in Salmonella minnesota. Journal of General Microbiology 48, 225-233.

Loeb, T. \& ZINDER, N. D. (I96I). A bacteriophage containing RNA. Proceedings of the National Academy of Sciences of the United States of America 47, 282-289.

Loomis, W. F. \& MAGASANIK, B. (1964). The relation of catabolite repression to the induction system for $\beta$-galactosidase in Escherichia coli. Journal of Molecular Biology 8, 417-426.

Lüderitz, O., Staub, A. M. \& WestPhal, O. (I966). Immunochemistry of O- and R-antigens of Salmonella and related enterobacteriaceae. Bacterial Reviews 30, 192-255.

Luria, S. E. (1964). Colicin-like effects of phage-ghosts. Annales de l'Institut Pasteur Io7, 67-72.

Mathews, C. K. (1971). Bacteriophage Biochemistry, p. 48. ACS Monograph I66. New York, Cincinnati, Toronto, London, Melbourne: Van Nostrand Reinhold.

Munder, P. G. \& Modollel, M. (1965). Fortlaufende registrierende Bestimmung der Zellatmung durch elektrochemische Sauerstoffmessung. Zeitschrift fiir Analytische Chemie 212, 177-187.

NAKADA, D. \& MAGASANIK, B. (1964). The roles of inducer and catabolite repressor in the synthesis of $\beta$-galactosidase by Escherichia coli. Journal of Molecular Biology 8, 105-127.

Newbold, J. E. \& Sinsheimer, R. L. (1970). The process of infection with bacteriophage $\phi$ XI74. XXXII. Early steps in the infection process: attachment, eclipse and DNA penetration. Journal of Molecular Biology 49, 49-66.

Nomura, M., Matsubara, K., Okamoto, K. \& Fujimura, K. (1962). Inhibition of host nucleic acid and protein synthesis by bacteriophage $\mathrm{T}_{4}$ : its relation to the physical and functional integrity of host chromosome. Journal of Molecular Biology 5, 535-549.

Novick, R. P. \& Brodsky, R. (I972). Studies on plasmid replication. I. Plasmid incompatibility and establishment in Staphylococcus aureus. Journal of Molecular Biology 5, 285-302.

Ørskov, F., Ørskov, I., JANN, B., JANN, K., Müller-Seitz, E. \& WeSTPHAL, O. (1967). Immunochemistry of Escherichia coli $\mathrm{O}$ antigens. Acta pathologica et microbiologica scandinavia $7 \mathbf{r}, 339-358$.

Pardee, A. B., JACOB, F. \& Monod, J. (1959). The genetic control and cytoplasmic expression of inducibility in the synthesis of $\beta$-galactosidase. Journal of Molecular Biology 1, 165-I 72 .

Puck, T. T. \& LEE, H. H. (1954). Mechanism of cell wall penetration by viruses. I. An increase in host cell permeability induced by bacteriophage infection. Journal of Experimental Medicine 99, 48 I-494.

Puck, T. T. \& LEE, H. H. (1955). Mechanism of cell wall penetration by viruses. II. Demonstration of cyclic permeability changes accompanying virus infection of Escherichia coli в cells. Journal of Experimental Medicine ror, I5I-162.

Rachelmeyer, M., Gerhart, J. \& Rosner, J. (I96I). Limited thymidine uptake in Escherichia coli due to an inducible thymidine phosphorylase. Biochimica et biophysica acta 49, 222-225.

Reske, K., WALlenfels, B. \& JANN, K. (1973). Enzymatic degradation of O-antigenic lipopolysaccharides by coliphage $\Omega$ 8. European Journal of Biochemistry 36, I67-171.

Rickenberg, H. V., Cohen, G. N., Butting, G. \& Monod, J. (1956). La galactoside perméase d'Escherichia coli. Annales de l'Institut Pasteur 9r, 829-857.

Schlecht, S. \& WestPhal, O. (I966). Wachstum und Lipopolysaccharid (O-Antigen)-Gehalt von Salmonellen bei Züchtung auf Agarnährböden I. Zentralblatt für Bakteriologie und Parasitenkunde (Orig.) 200, 24 I-259.

Simoni, R. B., Smith, M. F. \& Roseman, S. (1968). Resolution of a staphylococcal phosphotransferase system into four protein components and its relation to sugar transport. Biochemical and Biophysical Research Communications 31, 804-8I $\mathrm{I}$.

WestPhal, O. \& JANN, K. (1965) Bacterial lipopolysaccharide extraction with phenol-water and further applications of the procedure. Methods of Carbohydrate Chemistry 5, 83-9I.

Winkler, H. M. \& Duckworth, D. H. (1971). Metabolism of T4 bacteriophage ghost-infected cells: effect of bacteriophage and ghosts on the uptake of carbohydrates in Escherichia coli B. Journal of Bacteriology 107, 259-267.

WinkLER, H. M. \& WiLSON, T. H. (1965). Energy coupling in the transport of $\beta$-galactosides by Escherichia coli. Journal of Biological Chemistry 24I, 2200-22 I I.

YAGIL, E. \& Rosner, A. (1970). Effect of adenosine and deoxyadenosine on the incorporation and breakdown of thymidine in Escherichia coli. Journal of Bacteriology Ior, 417-42 I. 